\title{
ANALISIS KUALITAS AIR TANAH DI DESA LEPAK KECAMATAN SAKRA BARAT LOMBOK TIMUR
}

\author{
Muhammad Nizar ${ }^{1}$, Nanang Rahman ${ }^{2}$, dan Haifaturrahmah ${ }^{3}$ \\ ${ }^{1}$ Dosen Prodi Pend. Geografi FKIP UM Mataram, ${ }^{2}$ Dosen Prodi Pend. Fisika FKIP \\ UM Mataram, ${ }^{3}$ Dosen Prodi Pend. Geografi FKIP UM Mataram.
}

\begin{abstract}
Abstrak
Kesehatan lingkungan mencakup aspek lingkungan tanah, perairan, dan udara. Mengingat kondisi dekonstruksi lingkungan hidup saat ini pernting untuk terus dilakukan penelitian secara berkesinambungan terhadap kualitas lingkungan. Dalam penelitian ini, dilakukan analisis terhadap kualitas air pada lokasi sumur warga yang dekat dengan permukiman. Penelitian dilakukan di Desa Lepak Kabupaten Lombok Timur. Pengukuran parameter kualitas air dilakukan untuk mengukur parameter air tanah. Pengukuran parameter air tanah (suhu, warna, rasa/bau, keasaman/pH dan kandungan E. coli) di laboratorium dengan sampel yang diambil pada sumur yang telah ditentukan sebagai titik pengambilan sampel. Sementara untuk parameter rasa dan bau dilakukan pengamatan langsung di lapangan. Hasil penelitian menunjukkan bahwa kualitas air tanah secara parameter fisik (suhu, warna, kekeruhan,rasa dan bau) sudah memenuhi kriteria kualitas air bersih, berdasarkan parameter kimia mendekati $\mathrm{pH}$ air netral. Sedangkan parameter biologi (Escherchia Coli) tidak memenuhi kriteria kualitas air bersih yang dapat digunakan sebagai bahan baku air minum. Meskipun demikian sebelum diminum air bersih tersebut harus dilakukakan perlakuan (dimasak). Tingginya parameter biologi sudah melampaui ambang batas, menyebabkan air pada sumur-sumur tersebut tidak layak digunakan untuk air minum sebelum dimasak terlebih dahulu.
\end{abstract}

Kata kunci: parameter, kualitas air, uji 


\section{PENDAHULUAN}

Kondisi kesehatan lingkungan hidup sangat dipengaruhi oleh kualitas air, dan kehidupan masyarakat sangat bergantung pada air. Saat ini kondisi air bersih di daerah yang dipergunakan oleh masyarakat sehari-hari sangat memprihatinkan karena adanya kandungan limbah yang dapat diamati langsung maupun yang tidak dapat diamati langsung (melalui uji)

Pencemaran air dapat diartikan sebagai perubahan kualitas air akibat masuk atau dimasukkannya zat pencemar/polutan, hasil dari kegiatan manusia atau proses alam ke dalam badan air yang mengakibatkan kualitas air turun sampai tingkat tertentu sehingga tidak lagi sesuai dengan peruntukannya. Zat polutan yang mengakibatkan terjadinya pencemaran air dapat berasal dari kegiatan alam (proses alami) dan atau kegiatan manusia. Kegiatan gunung api dan proses alami lainnya dapat mempengaruhi kulitas sumberdaya air, baik yang terdapat di atas maupun di bawah permukaan tanah. Kegiatan manusia yang mempengaruhi kualitas air disebabkan oleh adanya limbah atau kotoran.

Beberapa jenis kegiatan manusia yang dapat menghasilkan limbah adalah dari sektor pemukiman penduduk, indusri pertambangan, pertanian, perdagangan, rekreasi dan transportasi. Sektor pemukiman dengan limbah domestiknya merupakan sumber pencemaran terbesar diatara sektor-sektor yang lain. Limbah domestik mengandung bahan pencemar organik, anorganik, dan bakteri yang potensial mencemari sumber daya air.

Desa Lepak merupakan daerah yang mengalami perkembangan pesat dengan pembangunan dan pertumbuhan penduduk terus meningkat dari hari kehari. Peningkatan jumlah penduduk yang besar menuntut pemenuhan kebutuhan akan sumber daya alam yang tidak sedikit, salah satunya adalah kebutuhan masyarakat akan air bersih.

Sebagian besar dari masyarakat Desa Lepak menggunakan sumur sebagai sarana pemenuhan kebutuhan air bersih. Ini berarti bahwa peranan air tanah masih sangat penting. Penelitian

74 BIOTA: Jurnal Tadris IPA Biologi FITK IAIN Mataram 
tentang kualitas air tanah sangat penting untuk mengetahui tingkat kualitas air tanah di daerah tersebut. Keterbatasan air bersih pada air tanah akan berdampak pada masalah kesehatan masyarakat di Desa Lepak, yaitu menimbulkan gejala penyakit diare dan muntaber.

Berdasarkan latar belakang yang telah diuraikan di atas, maka penelitian ini memfokuskan pada masalah identifikasi kualitas air tanah di Desa Lepak Kecamatan Sakra Barat Kabupaten Lombok Timur melalui analisis terhadap parameter fisika (suhu, warna, rasa dan bau), parameter kimia (keasaman/pH) dan parameter biologi (bakteri E. Coli).

Air tanah (ground water) adalah air yang berada di bawah permukaan tanah di dalam zona jenuh (saturation zone) dimana tekanan hidrostatiknya sama atau lebih besar dari tekanan atmosfer (Sosrodarsono, 1985).

Kandungan air tanah suatu daerah dapat dipengaruhi oleh banyaknya curah hujan, kondisi penutup lahan (land cover), bentuk lahan, kondisi batuan, dan aktivitas manusia. Sebagian besar air tanah berasal dari hujan yang meresap masuk ke dalam tanah. Proses masuknya air hujan ke dalam pori-pori tanah sangat dipengaruhi oleh vegetasi, jenis tanah dan bentuk lahan. Aktivitas manusia juga berpengaruh dimana aktivitasnya bisa memberikan perubahan yang positif/ negatif terhadap kondisi air tanah.

Parameter kualitas air secara umum terdiri dari sifat fisika, kimia dan biologi. Pada parameter fisika dapat ditinjau dari beberapa hal: suhu, warna, rasa dan bau. Untuk parameter kimia dapat ditinjau dari segi keasaman/pH dan parameter biologi ditinjau dari jumlah bakteri E.coli dalam air tanah.

\section{a. Parameter Fisika}

Dalam melakukan pengujian kulitas air dari aspek fisika, terdapat beberapa komponen yang harus diperhatikan diantaranya, suhu, warna, rasa dan bau :

1) Suhu

Suhu suatu badan air dipengaruhi oleh musim, lintang (latitude), ketinggian dari permukaan laut (altitude) waktu 
dalam hari, sirkulasi udara, penutupan awan dan aliran serta kedalaman badan air. Perubahan suhu berpengaruh terhadap proses fisika, kimia, dan biologi badan air. Suhu juga berperan mengendalikan ekosistem perairan. Organisme akuatik memiliki kisaran suhu tertentu yang disukai bagi pertumbuhannya. Peningkatan suhu mengakibatkan peningkatan viskositas, reaksi kimia, evaporasi, dan votalitisasi. Peningkatan suhu menyebabkan penurunan kelarutan gas dalam air, misalnya gas $\mathrm{O}_{2}, \mathrm{CO}_{2}, \mathrm{~N}_{2}, \mathrm{CH}_{4}$ dan sebagainya ( Hefni Effendi, 2003).

2) Warna

Adanya warna dalam air disebabkan oleh zat-zat yang terlarut di dalam air itu, karena itu harus dibedakan dengan kekeruhtan, yang disebabkan adanya zat-zat yang tidak larut. Warna dapat diamati secara visual (langsung) ataupun diukur berdasarkan skala platinum koblt (dinyatakan dengan Satuan PtCo), dengan membandingkan warna air sampel dan warna air standar. Warna dapat menghambat penetrasi cahaya ke dalam air dan mengakibatkan terganggunya proses fotosintesis. Perairan alami tidak berwarna. Air dengan nilai lebih kecil dari 10 PtCo biasanya tidak memperlihatkan warna yang jelas. Air yang berwarna kuning hingga kehitaman nilai warna 200 300 PtCo karena adanya asam humus ( Hefni Efendi, 2003).

3) Rasa dan Bau

Pengukuran rasa dan bau pada air dilakukan dengan pengamatan langsung di lapangan. Dalam penilaian kualitas air dapat dinyatakan secara langsung umpamanya air itu rasanya asin, asam pahit dan sebagainya. Demikian pula dengan baunya dapat diyatakan umpanya bau busuk, bau tanah, bau minyak dan sebagainya.

\section{b. Parameter Biologi}

Unit yang dipakai untuk mengukur bakteri adalah mikron (micron) yang panjangnya kira-kira sama dengan

76 BIOTA: Jurnal Tadris IPA Biologi FITK IAIN Mataram 
1/25.000 inchi. Bakteri-bakteri yang berada dalam air pada umumnya mempunyai panjang 1 sampai 4 mikron. Salah satu penyebab rasa dan bau dari air ialah adanya bakteri-bakteri akibat dari pencemaran yang dibawa air selokan atau air permukaan. Analisa bakteri penting dilakukan untuk keperluan air minum.

Sebagian besar bakteri patogen yang ditemukan dalam air sering menyebabkan penyakit usus pada binatang-binatang dan manusia. Penentuan bakteri patogen dalam air alami, sulit dilaksanakan, sedang jenis bakteri coli adalah relatif mudah ditentukan test standar untuk menentukan ada atau tidaknya dalam suatu contoh air dapat dipakai sebagai petunjuk langsung bagi suatu sumber air untuk keperluan air minum. Hasil test jenis bakteri coli dinyatakan sebagai jumlah kemungkinan terbesar dari bakteri jenis coli yang dikandung dalam suatu volume air. (Joko dan Karmono, 1978).

\section{c. Parameter Kimia}

Air normal yang memenuhi syarat untuk suatu kehidupan mempunyai pH sekitar 6,5 - 7,5. Air akan bersifat asam atau basa tergantung besar kecilnya $\mathrm{pH}$. Bila $\mathrm{pH}$ di bawah $\mathrm{pH}$ normal, maka air tersebut bersifat asam, sedangkan air yang mempunyai $\mathrm{pH}$ di atas $\mathrm{pH}$ normal bersifat basa. Air limbah dan bahan buangan industri akan mengubah $\mathrm{pH}$ air yang akhirnya akan mengganggu kehidupan biota akuatik. Sebagian besar biota akuatik sensitif terhadap perubahab $\mathrm{pH}$ dan menyukai $\mathrm{pH}$ antara 7 - 8,5. Nilai $\mathrm{pH}$ sangat mempengaruhi proses biokimiawi perairan, misalnya proses nitrifikasi akan berakhir pada $\mathrm{pH}$ yang rendah ( Hefni Efendi, 2003).

\section{METODE PENELITIAN}

Sasaran penelitian adalah Desa Lepak Kecamatan Sakra Kabupaten Lombok Timur. Untuk mengetahui kualitas air tanahnya penelitian dilakukan pada sumur-sumur yang digunakan oleh masyarakat di desa tersebut. 
Pengukuran parameter kualitas air dilakukan untuk mengukur parameter air tanah. Pengukuran parameter air tanah (suhu, warna, rasa/bau, keasaman/pH dan kandungan E. coli) di laboratorium dengan sampel yang diambil pada sumur yang telah ditentukan sebagai titik pengambilan sampel. Sementara untuk parameter rasa dan bau dilakukan pengamatan langsung di lapangan.

Teknik lainnya juga yang digunakan untuk mengumpulkan informasi adalah wawancara, teknik ini diartikan sebagai suatu cara memperoleh keterangan, pendirian, pendapat secara lisan dari seseorang yang lazim disebut responden yakni ibu rumah tangga atau seseorang yang mempunyai sumur, kades, puskesmas, dan masyarakat setempat.

Data yang diperoleh dari hasil uji di laboratorium berupa data hasil uji parameter fisika, kimia dan biologi kemudian dibandingkan dengan tabel kriteria kualitas air yang dapat digunakan sebagai air minum untuk mengetahui tingkat kualitas air tanah di Desa Lepak.

Tabel 1

Baku Mutu Air Sehat, Air Bersih, Air Tercemar, dan Air Baku

\begin{tabular}{|c|c|c|c|c|c|c|}
\hline \multirow[b]{2}{*}{ No } & \multirow[b]{2}{*}{ Parameter } & \multirow[b]{2}{*}{ Satuan } & \multicolumn{4}{|c|}{ Kadar maksimum } \\
\hline & & & Air sehat & Air bersih & $\begin{array}{c}\text { Air } \\
\text { tercemar }\end{array}$ & Air baku \\
\hline 1 & $\begin{array}{l}\text { FISIKA } \\
\text { Suhu } \\
\text { Warna } \\
\text { Rasa } \\
\text { Bau }\end{array}$ & ${ }^{\circ} \mathrm{C}$ & $\begin{array}{l}10-25 \\
\text { tidak } \\
\text { berwarn } \\
\text { a } \\
\text { Tidak } \\
\text { berasa } \\
\text { Tidak } \\
\text { Berbau }\end{array}$ & $\begin{array}{l}20-30 \\
\text { tidak } \\
\text { berwarna } \\
\text { Tidak } \\
\text { berasa } \\
\text { Tidak } \\
\text { Berbau }\end{array}$ & $\begin{array}{l}0-50 \\
\text { Berwarna } \\
\text { Berasa } \\
\text { Berbau }\end{array}$ & $\begin{array}{l}100 \\
\text { tidak } \\
\text { berwarn } \\
\text { a } \\
\text { Tidak } \\
\text { berasa } \\
\text { Tidak } \\
\text { Berbau }\end{array}$ \\
\hline 2 & $\begin{array}{l}\text { BIOLOGI } \\
\text { Kandungan } \\
\text { E.Coli }\end{array}$ & $\begin{array}{l}50 \\
\text { koloni } \\
/ \\
100 \mathrm{~mL}\end{array}$ & 0 & 0 & $\begin{array}{l}5 \\
\text { koloni/mL }\end{array}$ & 0 \\
\hline
\end{tabular}

78 BIOTA: Jurnal Tadris IPA Biologi FITK IAIN Mataram 


\begin{tabular}{|l|l|l|l|l|l|l|}
\hline 3 & $\begin{array}{l}\text { KIMIA } \\
\text { Keasaman/ } \\
\text { Ph }\end{array}$ & $6,5-7,5$ & $7-8,5$ & $\begin{array}{l}<6,5 \\
>8,5\end{array}$ & \\
\hline
\end{tabular}

Sumber: D.K.Kalsim, 2008

Mutu air minum sehat dan air bersih berdasarkan Peraturan Menteri Kesehatan Republik Indonesia, No 416/Menkes/Per/IX/1990, Tanggal 3 September 1990 Mutu air baku mutu Golongan A berdasarkan Peraturan Menteri Kesehatan Republik Indonesia, No 173/Menkes/Per/VIII/77, Tahun 1977. Indikator atau tanda bahwa air lingkungan telah tercemar adalah adanya perubahan atau tanda yang dapat diamati yang dapat digolongkan menjadi :

a. Pengamatan secara fisik, yaitu pengamatan pencemaran air berdasarkan tingkat kejernihan air (kekeruhan), perubahan suhu, warna dan adanya perubahan warna, bau dan rasa.

b. Pengamatan secara kimiawi, yaitu pengamatan pencemaran air berdasarkan zat kimia yang terlarut, perubahan $\mathrm{pH}$

c. Pengamatan secara biologis, yaitu pengamatan pencemaran air berdasarkan mikroorganisme yang ada dalam air, terutama ada tidaknya bakteri pathogen,atau kandungan (E.Coli).

\section{HASIL PENELITIAN DAN PEMBAHASAN}

Dalam pengambilan sampel, diklasifikasi menjadi 3 lokasi yaitu: Dusun Lepak, Dusun Gelogor dan Dusun Kondak. Pemilihan sumur sampel tiap-tiap dusun dipilih dengan jarak masing-masing sumur sampel sekitar $500 \mathrm{~m}$ dan dipilih sumur warga yang kiranya disekitar lokasi tersebut terdapat gejala-gejala yang dapat mencemarkan air sumur sampel.

\section{a. Lokasi 1 (Dusun Lepak )}

Sumur 1:

Kondisi sumur 1 berdekatan dengan gang, dengan sistem pembuangan air buangan drainase terbuka langsung keselokan gang. Jarak gang dengan sumur $2 \mathrm{~m}$, sedangkan jaraknya dengan septick tank hanya 5 m. Kedalaman air sumur sekitar 4 
m dari muka tanah dengan kondisi dinding lubang sumur masih berupa tanah, sedangkan atasnya dibiarkan terbuka.

Sumur 2:

Kondisi sumur 2 jauh dari jalan raya utama sekitar $40 \mathrm{~m}$, tetapi berdekatan dengan area sawah penduduk sekitar $3 \mathrm{~m}$ dari petak sawah terdekat. Pembuangan air buangan atau air sisa menggunakan drainase terbuka dialirkan langsung ke tanah tanpa ada jalur got atau parit tersendiri, sehingga air buangan tergenang disekitar sumur. Jarak sumur dengan septick tank sekitar $15 \mathrm{~m}$. Kedalaman air sumur sekitar $5 \mathrm{~m}$ dengan kondisi dinding lubang sudah dibuis beton dan atasnya tidak tertutup.

b. Lokasi 2 (Dusun Gelogor)

Sumur 1:

Kondisi sumur 1 dusun Pai Dalam berdekatan dengan sungai, dengan sistem pembuangan air buangan drainase terbuka langsung ke sungai. Jarak sungai dengan sumur $8 \mathrm{~m}$, sedangkan jaraknya dengan septick tank sekitar $9 \mathrm{~m}$. Kedalaman air sumur sekitar $8 \mathrm{~m}$ dari permukaan tanah dengan kondisi dinding lubang sumur menggunakan buis beton, sedangkan atasnya dibiarkan terbuka. Letak sumur jauh dari jalan raya utama yaitu posisinya ditengah pemukiman penduduk.

\section{Sumur 2:}

Kondisi sumur 2 ini berdekatan dengan jalan lingkungan penduduk, dengan sistem pembuangan air buangan drainase terbuka langsung keselokan jalan. Jarak jalan lingkungan dengan sumur $3 \mathrm{~m}$, dan posisi sumur lebih rendah levelnya dari jalan. jarak sumur dengan septick tank terdekat $4 \mathrm{~m}$. Kedalaman air sumur sekitar $5 \mathrm{~m}$ dari muka tanah dengan kondisi dinding lubang sumur masih berupa tanah, sedangkan atasnya tidak ditutup. 


\section{c. Lokasi 3 (Dusun Kondak)}

Sumur 1:

Posisi sumur 1 berdekatan dengan jalan raya umum yaitu hanya $3 \mathrm{~m}$. Kedalaman air sumur sekitar 10 dari muka tanah, kondisi disekitar sumur tidak terawat. Air buangan dari sumur dialirkan langsung ke tanah tanpa ada selokan sehingga air buangan tergenang disekitar sumur dan mengalir juga ke Jalan Raya. Kondisi fisik sumur sudah dibuis beton dan jaraknya dari septick tank cukup jauh yaitu sekitar $20 \mathrm{~m}$.

Sumur 2:

Posisi sumur 2 dari jalan raya sekitar $30 \mathrm{~m}$. Sumur di pagar keliling oleh pemilik dan sekitarnya banyak pohon pisang. Kondisi lubang sumur sudah menggunakan buis beton dengan kedalaman air sekitar $7 \mathrm{~m}$. Air buangan sumur dialirkan ketanah menggunakan selokan kemudian dialirkan ke kebun pisang.

Cara pengambilan sampel air dilakukan dengan teknik sebagai berikut:

1. Menyiapkan botol untuk pengambilan sampel air. 6 botol untuk parameter Fisika dan 6 botol untuk parameter Biologi dan 6 botol untuk parameter kimia. Parameter Biologi ada botol khusus yang sudah disterilkan sedangkan parameter Fisika dan kimia memakai botol biasa. Dalam satu sumur diambil 3 botol sample untuk, 1 parameter fisika dan 1 parameter biologi dan parameter kimia.

2. Sebelum pengambilan sampel air, tangan disterilisasi dengan menggunakan alkohol dan diusahakan agar tidak menyentuh langsung ujung kepala botol yang sudah disterilisasi. Botol dicuci menggunakan air sumur itu sendiri sebanyak 3 kali. Sterilisasi botol dilakukan dengan cara dipanaskan ujungnya selama 2 menit.

3. Air sumur diambil dengan timba dan timba air tersebut tidak boleh menyentuh dinding sumur. Air dimasukkan kedalam botol menggunakan gelas stainless yang sudah dicuci sebanyak 3 kali dengan air sumur yang sama. 
4. Setelah selesai semua pengambilan sampel air pada enam sumur, botol yang berisi air ditempelkan kode ditiap-tiap botol sampel air dan dimasukan kedalam box es, dibungkusi dengan plastik es dan kemudian diawetkan dengam es batu. Pengambilan sampel air tidak boleh lebih dari 24 jam sebelum dilakukan penelitian.

Berikut diuraikan hasil dan pembahasan penelitian

\section{Parameter Fisiki}

Parameter fisika dalam penelitian ini adalah : parameter suhu, warna, kekeruhan, rasa dan bau. Hasil pengukuran parameter fisik dapat dilihat pada tabel berikut.

Tabel 2

Hasil Analisis Parameter Fisika

\begin{tabular}{|c|c|c|c|c|c|c|c|c|}
\hline \multirow[b]{3}{*}{$\begin{array}{l}\mathbf{N} \\
\mathbf{o}\end{array}$} & \multirow[b]{3}{*}{$\begin{array}{l}\text { Parameter } \\
\text { (Satuan) }\end{array}$} & \multicolumn{7}{|c|}{ Lokasi Sampel } \\
\hline & & \multicolumn{2}{|c|}{ Dusun lepak } & \multicolumn{2}{|c|}{ Dusun gelogor } & \multicolumn{2}{|c|}{ Dusun kondak } & \multirow{2}{*}{$\begin{array}{c}\text { Kriteria } \\
\text { Max yang } \\
\text { diperbolehk } \\
\text { an }\end{array}$} \\
\hline & & $\underset{I}{\text { Sumur }}$ & $\underset{\text { II }}{\text { Sumur }}$ & $\underset{\text { I }}{\text { Sumur }}$ & $\underset{\text { II }}{\text { Sumur }}$ & $\underset{\text { I }}{\text { Sumur }}$ & $\underset{\text { II }}{\text { Sumur }}$ & \\
\hline 1 & Suhu $\left({ }^{\circ} \mathrm{C}\right)$ & 27,0 & 27,0 & 27,0 & 27,0 & 27,0 & 27,0 & $20-30^{\circ} \mathrm{C}$ \\
\hline 2 & Warna (TCU) & 5 & 5 & 5 & 5 & 5 & 5 & 25 \\
\hline 3 & $\begin{array}{l}\text { Kekeruhan } \\
\text { (NTU) }\end{array}$ & 8,0 & 9,8 & 12,0 & 11,1 & 10,0 & 12,0 & 15 \\
\hline 4 & Rasa & $\begin{array}{c}\text { Tdk } \\
\text { berasa }\end{array}$ & $\begin{array}{c}\text { Tdk } \\
\text { berasa }\end{array}$ & $\begin{array}{c}\text { Tdk } \\
\text { berasa }\end{array}$ & $\begin{array}{c}\text { Tdk } \\
\text { berasa }\end{array}$ & $\begin{array}{c}\text { Tdk } \\
\text { berasa }\end{array}$ & $\begin{array}{c}\text { Tdk } \\
\text { berasa }\end{array}$ & Tdk berasa \\
\hline 5 & Bau & $\begin{array}{c}\text { Tdk } \\
\text { berbau }\end{array}$ & $\begin{array}{c}\text { Tdk } \\
\text { berbau }\end{array}$ & $\begin{array}{c}\text { Tdk } \\
\text { berbau }\end{array}$ & $\begin{array}{c}\text { Tdk } \\
\text { berbau }\end{array}$ & $\begin{array}{c}\text { Tdk } \\
\text { berbau }\end{array}$ & $\begin{array}{c}\text { Tdk } \\
\text { berbau }\end{array}$ & Tdk berbau \\
\hline
\end{tabular}

a. Suhu

Dilihat dari parameter suhu (temperatur) semua lokasi sampel masih dalam kategori normal. Hasil pengukuran suhu berkisar $27^{\circ} \mathrm{C}-28^{\circ} \mathrm{C}$. sementara diketahui bahwa temperatur yang diperbolehkan dalam kriteria kualitas air adalah temperatur air alam yaitu berkisar antara $20^{\circ} \mathrm{C}-30^{\circ} \mathrm{C}$ (Effendi, 2003).

82 BIOTA: Jurnal Tadris IPA Biologi FITK IAIN Mataram 
b. Warna

Dari tabel di atas dapat dilihat bahwa hasil dari 6 sampel diatas memenuhi kriteria kualitas air bersih untuk parameter warna, sama-sama hasil 5 TCU. Parameter warna diuji dengan alat kolorimetri berbentuk kertas bulat berwarna dan dapat dilakukan dengan mengamati langsung dengan penglihatan normal. Cara menguji parameter warna cukup sederhana, air sampel dan Aqua dum dimasukkan kedalam gelas ukur masing-masing, kemudian disimpan diatas alat kolorimetri dan dibandingkan air sampel dengan aqua dum.

Dari pengamatan ini bisa dibedakan secara langsung mana yang jernih dan mana yang masih terkandung zat-zat lain dalam air tersebut. Warna air dapat di pengaruhi oleh bahan-bahan kimia terlarut dan juga oleh bahan tersuspensi.

c. Kekeruhan

Tingkat kekeruhan dari hasil 6 sampel memenuhi kriteria kualitas air bersih, tetapi tidak dapat langsung diminum melainkan dimasak terlebih dahulu baru bisa dikonsumsi untuk air minum. Hal ini dikarenakan masih tingginya tingkat kekeruhan air baku dari sumur yaitu diatas standar yang disarankan. Alat untuk mengukur kekeruhan yaitu metode Turbidimeter dengan cara kerja dicelupkan alat tersebut ke dalam sampel air yang diberikan kode masingmasing lokasi sampel air. Angka tingkat kekeruhan dapat dilihat langsung pada layar atau screen Tubidimeter dimana semakin keruh maka angka pada alat akan bertambah naik.

d. Rasa dan bau

Parameter rasa dan bau dapat dilakukan pengukuran langsung di lapangan yaitu dengan menggunakan indera perasa dan indra penciuman normal. Pada tabel 4.1 terlihat bahwa untuk parameter rasa dan bau semua lokasi sama yaitu airnya tidak berasa dan berbau. Dilihat dari kondisi fisik masing-masing lokasi, perbedaan ada atau tidaknya bau pada air disebabkan oleh benda asing yang masuk ke dalam air seperti bangkai bintang, bahan buangan, ataupun disebabkan 
oleh adanya proses penuraian senyawa organik oleh bakteri (Pitojo dan Eling, 2002).

\section{Parameter Biologi}

Yang menjadi parameter biologi dalam penelitian ini adalah parameter Escherchia Coli. Hasil pengukuran parameter dapat dilihat pada tabel berikut.

Tabel 3

Hasil Analisis Parameter Biologi

\begin{tabular}{|c|c|c|c|c|c|c|c|}
\hline \multirow{2}{*}{$\begin{array}{c}\text { Parameter } \\
\text { (Satuan) }\end{array}$} & \multicolumn{6}{|c|}{ Lokasi Sampel } \\
\cline { 2 - 6 } & $\begin{array}{c}\text { Sumur } \\
\text { I }\end{array}$ & $\begin{array}{c}\text { Sumur } \\
\text { II }\end{array}$ & $\begin{array}{c}\text { Sumur } \\
\text { I }\end{array}$ & $\begin{array}{c}\text { Sumur } \\
\text { II }\end{array}$ & $\begin{array}{c}\text { Sumur } \\
\text { I }\end{array}$ & $\begin{array}{c}\text { Sumur } \\
\text { II }\end{array}$ & $\begin{array}{c}\text { Kriteria Max yang } \\
\text { diperbolehkan }\end{array}$ \\
\hline $\begin{array}{c}\text { Escherchia } \\
\text { Coli } \\
\text { (MPN/100 } \\
\text { ml) }\end{array}$ & 350 & 280 & $\geq 2.400$ & 1.600 & 1.600 & 350 & 50 \\
\hline
\end{tabular}

Dari tabel di atas dapat diketahui bahwa parameter Escherchia Coli (E.Coli) dari 6 sampel air sumur tidak ada satupun yang termasuk atau memenuhi syarat kriteria air bersih. Dipengaruhi oleh pencemaran karena dekatnya air sumur pada tempat pembuangan kotoran (jamban), septick tank, kotoran hewan/sampah, genangan air dan sungai sehingga menyebabkan air sumur banyak mengandung bakteri E.Coli. Peraturan pemerintah dianjurkan seharusnya posisi sumur dengan jamban kotoran hewan/sampah, genangan air dan sungai berjarak $10 \mathrm{~m}$ dari sumur.

Dari hasil penelitian bakteri Escherchia Coli tidak ada yang memenuhi syarat air bersih. Semua lokasi penelitian merupakan daerah pemukiman biasa memungkinkan terjadinya pencemaran air tanah oleh kotoran manusia dan hewan.

84 BIOTA: Jurnal Tadris IPA Biologi FITK IAIN Mataram 


\section{Parameter Kimia}

Pengukuran terhadaptingkat kasaman menggunakan alat $\mathrm{pH}$ meter, hal ini bertujuan untuk mendapatkan tingkat keakuratan yang sangat tinggi. Berdasarkan hasil pengamatan di desa Lepak terhadap sampel air tanah, di dapatkan data sebagai berikut:

\section{Tabel 4}

Hasil Analisis Parameter Kimia

\begin{tabular}{|c|c|c|c|c|c|c|c|}
\hline \multirow{3}{*}{$\begin{array}{l}\text { Parameter } \\
\text { (Satuan) }\end{array}$} & \multicolumn{7}{|c|}{ Lokasi Sampel } \\
\hline & \multicolumn{2}{|c|}{ Dusun lepak } & \multicolumn{2}{|c|}{ Dusun gelogor } & \multicolumn{2}{|c|}{ Dusun kondak } & \multirow[b]{2}{*}{ pH air netral } \\
\hline & $\begin{array}{c}\text { Sumur } \\
\text { I }\end{array}$ & $\begin{array}{c}\text { Sumur } \\
\text { II }\end{array}$ & $\underset{\text { I }}{\text { Sumur }}$ & $\begin{array}{l}\text { Sumur } \\
\text { II }\end{array}$ & $\underset{\text { I }}{\text { Sumur }}$ & $\begin{array}{l}\text { Sumur } \\
\text { II }\end{array}$ & \\
\hline $\begin{array}{c}\text { Tingkat } \\
\text { keasaman }(\mathrm{pH})\end{array}$ & 6,3 & 6.5 & 6,1 & 6,0 & 5,8 & 6,0 & 7 \\
\hline
\end{tabular}

\section{KESIMPULAN DAN SARAN}

Hasil penelitian menunjukkan bahwa kualitas air tanah secara parameter fisik (suhu, warna, kekeruhan, rasa dan bau) sudah memenuhi kriteria kualitas air bersih, berdasarkan parameter kimia mendekati $\mathrm{pH}$ air netral. Sedangkan parameter biologi (Escherchia Coli) tidak memenuhi kriteria kualitas air bersih yang dapat digunakan sebagai bahan baku air minum. Meskipun demikian, sebelum diminum air di sumur-sumur warga Desa Lepak harus dimasak. Tingginya parameter biologi sudah melampaui ambang batas, menyebabkan air pada sumur-sumur tersebut sudah tidak layak untuk air minum sebelum dimasak terlebih dahulu. Masyarakat perlu meningkatkan perhatian dan kepeduliannya terhadap lingkungan demi kelestarian sumber daya alam termasuk dalam hal ini air tanah 


\section{DAFTAR PUSTAKA}

D.K.Kalsim.2008.kualitas-dan-kuantitas-baku-mutu-air-bersihuntuk-pemenuhan-kebutuhananusia.Jakarta./http://uripsantoso.wordpress.com/2009/ 17/4/kualitas-dan-kuantitas-baku-mutu-air-bersih-untukpemenuhan-kebutuhan-manusia/. Di unggah pada tanggal 15 februari 2014.Pukul 11.00.

Darmanto, Darmakusumah. 1999. Pengelolaan Sumber Daya Air, Catatan Kuliah. Fakultas geografi UGM. Yogakarta.

Effendi, Hefni. 2003. Telaah Kualitas Air. Kanisius. Yogyakarta.

Joko dan Karmono. 1978. Pengantar Penentuan Kualitas Air. Laboratorium Hidrologi. UGM. Yogyakarta

Sosrodarsono dan Takeda. 1985. Hidrologi Untuk Pengairan. PT. Pratnya Paramita. Jakarta

Sugiyono, MS. 1995. Pengelolaan Sumber Daya Air. Program Pascasarjana. UGM. Yogyakarta. 